\title{
Cytotoxic Activity of Cyclamen Persicum Ethanolic Extract on MCF-7, PC-3 and LNCaP Cancer Cell Lines
}

\author{
Walid M. Khalilia \\ Forensic Science Department, Al- Istiqlal University, PO. Box 10, Jericho, Palestine
}

\begin{abstract}
It is important to develop new approaches to increase the efficacy of cancer treatments. Nowadays, the uses of natural products to treat cancer are very common. In addition, working with plants that are endemic to Palestine and determining the biological activities of these plant extracts, is extremely important due to the potential for new drug development. Cyclamen persicum is used in traditional medicinal to treat anti-rheumatic, diarrhea, abdominal pains, edema, abscesses, eczema, cancer and other ailments. In this study the cytotoxic effect of C. persicum tubers and leaves ethanolic extracts were studied against MCF-7, PC-3 and LNCaP cancer cell lines, using mitochondrial dehydrogenase enzyme method. Results showed the remarkable cytotoxic activity of $C$. persicum extracts, against breast and prostate adenocarcinoma. For tubers extract the $\mathrm{IC}_{50}$ value was found to be $0.05 \mathrm{mg} / \mathrm{ml}$ for the three cell lines. Although the leaves extract the $\mathrm{IC}_{50}$ value was found to be $0.25 \mathrm{mg} / \mathrm{ml}$ for PC-3 and MCF-7 cell lines, while LNCaP cell inhibition were less than $30 \%$ at all tested leaves extract concentrations. MCF-7 cells exhibited the highest sensitivity to the $C$. persicum extracts, compared to PC-3 and LNCaP cell lines evaluated. In contrast, LNCaP cells generally exhibited the lowest sensitivity to extracts. These results displayed that $C$. persicum is a good source for natural products with antitumor compounds that can be further exploited for the development of a potential therapeutic anticancer agent.
\end{abstract}

Key words: Cyclamen persicum, Cytotoxicity, MTT assay, LNCaP, MCF-7, PC-3.

DOI: $10.7176 / \mathrm{JNSR} / 10-2-05$

Publication date: January $31^{\text {st }} 2020$

\section{Introduction}

Cancer is a genomic disease that appears as a result of dynamic changes of the DNA of an organism's cells during its life time. The burden of cancer is increasing worldwide with 14.1 million new cancer cases yearly and 8.2 million cancer deaths occurring in 2012 according to GLOBOCAN series (Ferlay et al., 2014). In Palestine, the most common cause of death out of all cancer types was lung cancer among males $(22.8 \%)$ and breast cancer among females $(21.5 \%)$ followed by prostate cancer for males $(9.5 \%)$ and by colon cancer for females $(11.4 \%)$ (Abu-Rmeileh et al., 2016).

It is important to develop new approaches to increase the antitumor effects against cancer cells in order to increase the efficacy of cancer treatments. Today, the uses of natural products to treat cancer are very common, in the world. However, some plants have not yet been scientifically proven to exert antitumor activity. Therefore, it is very important to study endemic plant extracts with unknown biological activities to possibly develop new drugs that will guide the intentional use of natural medicines (Ozcan et al., 2016).

Regional traditional medicinal plants and herbs will be served as a potential source of novel therapeutic agents. A large number of regional medicinal plants are claimed to possess anticancer activity. A systematic review conducted in Palestine, by Ali-Shtayeh and Jamous, 2014 identified a total of 368 plant species used in Traditional Arabic Palestinian Herbal Medicine (TAPHM) as part of complementary and alternative medicine (CAM). Some of these plants claimed to be effective in the treatment of cancer such as Cyclamen persicum, Arum palaestinum, Nigella ciliaris, Matricaria aurea, Salvia fruticosa, Zingiber officinale, Anisum vulgare, Allium sativum , Trigonella berythea, Curcuma longa, Majorana syriaca, Rosmarinus officinalis, Allium cepa ,Olea europaea, Camellia thea, and Teucrium capitatum (Ali- Shtayeh et al., 2000; Khalilia, 2001; Ali-Shtayeh and Jamous, 2008; Ali- Shtayeh et al., 2011; Jaradat et al., 2016). Recently, the ability of medicinal plant extracts to control the proliferation of cancer cells were reported (Yaacob et al., 2010; Alzeer et al., 2014; Ozcan et al., 2016).

Cyclamen persicum Mill. is a species of flowering herbaceous perennial plant of the Primulaceae family, growing from a tuber, native to rocky hillsides, scrublands, and woodlands in the Mediterranean area. $C$. persicum used in traditional medicinal to treat antirheumatic, headache, goiter, antihelmintic, laxative, diarrhea, abdominal pains, eye infections, edema, nerve infections, female infertility, open wounds, abscesses, eczema, skin burns, toothache, cancer and other ailments (Ali- Shtayeh et al., 2000; Khalilia, 2001; Ali- Shtayeh et al., 2011; Fernández-Campos et al., 2019; Al-zuabe et al., 2019).

To the best of our knowledge $C$. persicum has not yet been studied for their antitumoral activities against PC3 and LNCaP prostate cancer cells and MCF-7 cervical cancer cells.

The aims of this study, was to demonstrate the antitumor effect of $C$. persicum on various cancer cell lines, to compare the cytotoxicity of tubers and leaves extracts and determining whether their use in folkloric medicine to treat cancer disease is justified. 


\section{Materials and methods}

\subsection{Plant Collection}

Tubers and leaves of C. persicum were collected between March and July from Nablus mountains (West Bank, Palestine) (altitude 600-900 m). Authentification of the plants was conducted by Prof. Dr. Ali-Shtayeh by comparison with plant specimens located at BERC Herbarium and voucher specimens were deposited in the Biodiversity and Biotechnology Research Unit at BERC Herbarium, Til, Nablus, Palestine.

\subsection{Preparation of crude extracts}

Tubers and leaves of $C$. persicum $(100 \mathrm{~g})$ dried in the shade at room temperature, powdered and infused in $70 \%$ ethanol $(1: 5 \mathrm{w} / \mathrm{v})$ at room temperature with periodic shaking for $72 \mathrm{~h}$. The filtrates were condensed by evaporating the solvents using rotary evaporator, dried under reduced pressure, and stock solutions of $10 \mathrm{mg} / \mathrm{ml}$ in dimethyl sulphoxide (DMSO) were prepared at room temperature and stored at $-20^{\circ} \mathrm{C}$. (Ali-Shtayeh et al., 2013).

\subsection{Cell lines}

Prostate cancer PC-3 and LNCaP adenocarcinoma and breast cancer MCF-7 adenocarcinoma cell lines were obtained from American Type Culture Collection, USA (ATCC). MCF-7 and LNCaP cell lines were cultured in RPMI-1640 medium (Sigma), while PC-3 cell line was cultured in Minimum Essential Medium (MEM, Sigma). Medium were supplemented with 10\% fetal calf serum (FCS, Sigma), 2 mM L-Glutamine, $100 \mathrm{IU} / \mathrm{ml}$ penicillin and $100 \mu \mathrm{g} / \mathrm{ml}$ streptomycin (Sigma). Cell lines were incubated at $37{ }^{\circ} \mathrm{C}$ in a humidified incubator containing $5 \%$ CO2 (Bahk et al., 1998; Kelner et al., 1998; Eilon et al., 2000).

\subsection{Cytotoxicity}

Cells were seeded in 96 well- plates at a density of $4 \times 10^{4}$ cell/ $200 \mu 1$ for LNCaP cells, while $3 \times 10^{4}$ cells/ $200 \mu 1$ for PC-3 and MCF-7cell lines. The cells were allowed to attach in a 5\% CO2 incubator at $37^{\circ} \mathrm{C}$ for $24 \mathrm{~h}$. In order to prepare the 4 different doses of extracts $(0.05,0.125,0.25$ and $0.5 \mathrm{mg} / \mathrm{ml})$, crude extract was serially diluted into supplemented media using a separate 96-well plate and extract doses applied to the cells. After incubation for 24 hours viable cells were quantitated by using 3-[4,5-dimethyl thiazol-2-yl]-2,5-diphenyl tetrazolium bromide (MTT) (MERCK, Germany) assay. In brief after cells incubation for 24 hours, medium was aspirated carefully and discarded. After that $50 \mu \mathrm{l}$ of MTT solution $(1.5 \mathrm{mg} / \mathrm{ml})$ was added to each well and incubated for $3 \mathrm{~h}$, then 100 $\mu \mathrm{l}$ of iced acetone-ethanol solution (1:1) were added to dissolve violet crystals. Viability was quantitated by using a 96 well- plate reader at $570 \mathrm{~nm}$ wavelength, with a reference wave length of $650 \mathrm{~nm}$. The percentage of cell survival was determined as (mean of treated wells/ mean of untreated control wells) x100\%. DMSO was used as a negative control (Srivastava et al., 1998; Ozcan et al., 2016).

\subsection{Statistical analysis}

$\mathrm{IC}_{50}(50 \%$ growth inhibition) values were defined as the concentration of the extract where there is a $50 \%$ loss of total metabolic activity as compared to untreated controls and are reported as mean \pm standard deviation (SD). The data were analyzed and the treatment were compared using analysis of variance (ANOVA) obtained by Duncan's multiple-range test and $P$ values less than 0.05 were considered to be significant. All experiments have been conducted in three replicates.

\section{Results}

In order to evaluate the cytotoxic effect of ethanolic extracts from $C$. persicum (tubers and leaves), MTT assay with three different cancer cell lines (PC3, LNCaP, and MCF-7) were performed. To determine the $\mathrm{IC}_{50}$ value the extracts were screened for its cytotoxicity at different concentrations $(0.05,0.125,0.25$ and $0.5 \mathrm{mg} / \mathrm{ml})$.

When cells treated with ethanolic extract of the tubers and leaves of $C$. persicum, there was a concentration dependent cytotoxic effect. As the concentration increased from $0.05-0.5 \mathrm{mg}$, percentage of inhibition increases (Table 1). 
Table 1. Cytotoxicity of $C$. persicum against PC-3, MCF-7 and LNCaP cells treated with 4 different doses of ethanolic extracts after a $24 \mathrm{~h}$. (MTT assay).

\begin{tabular}{|c|c|c|c|c|}
\hline \multirow{2}{*}{$\begin{array}{c}\text { C. persicum } \\
\text { parts used }\end{array}$} & Concentration(mg/ml) & \multicolumn{3}{|c|}{ \%o of cell inhibition \pm SD. } \\
\cline { 2 - 5 } Tubers & & PC-3 & MCF-7 & LNCaP \\
\cline { 2 - 5 } & 0.5 & $94.6 \pm 3.5$ & $95.7 \pm 2.1$ & $90.3 \pm 3.5$ \\
\cline { 2 - 5 } & 0.25 & $77.6 \pm 4.6$ & $85.2 \pm 6.5$ & $79.1 \pm 1.5$ \\
\cline { 2 - 5 } & 0.125 & $62.3 \pm 8.2$ & $73.4 \pm 2.1$ & $65.6 \pm 3.2$ \\
\cline { 2 - 5 } & 0.05 & $45.2 \pm 5.2$ & $68.3 \pm 7.4$ & $51.1 \pm 3.4$ \\
\hline \multirow{4}{*}{ Leaves } & $0($ Control) & 0 & 0 & 0 \\
\cline { 2 - 5 } & 0.5 & $69.4 \pm 7.8$ & $63.2 \pm 10.6$ & $28.3 \pm 7.1$ \\
\cline { 2 - 5 } & 0.25 & $29.8 \pm 3.9$ & $55.1 \pm 8.8$ & $24.9 \pm 3.5$ \\
\cline { 2 - 5 } & 0.125 & 0 & $38.3 \pm 2.1$ & $23.2 \pm 6.4$ \\
\cline { 2 - 5 } & 0.05 & $28.2 \pm 7.4$ & 0 \\
\hline
\end{tabular}

This study showed the remarkable cytotoxic activity of $C$. persicum extracts, against breast and prostate adenocarcinoma. For tubers extract the $\mathrm{IC}_{50}$ value was found to be $0.05 \mathrm{mg} / \mathrm{ml}$ for the three cell lines. While the leaves extract the $\mathrm{IC}_{50}$ value was found to be $0.25 \mathrm{mg} / \mathrm{ml}$ for PC-3 and MCF-7 cell lines, but LNCaP cell inhibition were less than $30 \%$ at all tested leaves extract concentrations (Table 1. \& Figure 1.).

MCF-7 cells exhibited the highest sensitivity to the $C$. persicum extracts, with lower $\mathrm{IC}_{50}$ values as compared to PC-3 and LNCaP cell lines evaluated. In contrast, LNCaP cells generally exhibited the lowest sensitivity to the plant extracts (Table 1).

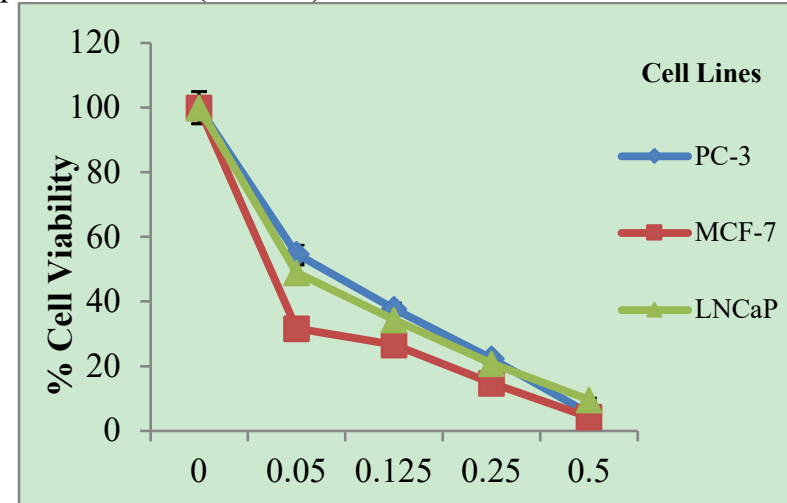

Extracts Dose Concentration $(\mathrm{mg} / \mathrm{ml})$

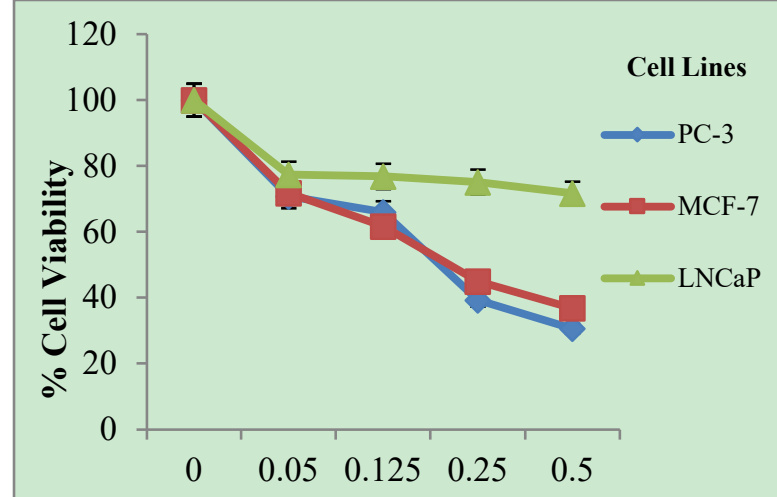

Extracts Dose Concentration $(\mathrm{mg} / \mathrm{ml})$

$\mathbf{A}$

B

Figure 1. \% Cell viability of PC3, LNCaP, and MCF-7 cell lines after 24 hours incubation with ethanolic extracts prepared from C. persicum tubers (A) and leaves (B). Cell viability was determined using MTT assay. Results are expressed as mean \pm S.D $(\mathrm{N}=2)$.

Figure 1 shows that a significant decrease in cell viability with $0.05,0.125,0.25$ and $0.5 \mathrm{mg} / \mathrm{ml}$ from $C$. persicum tuber extracts after $24 \mathrm{~h}$., and all doses showed viability by $10 \%$ at $0.5 \mathrm{mg} / \mathrm{ml}$ when compared with the control group. Cell viability decreased with increasing of leaves extracts concentration and all doses showed cell viability less than $30 \%$ at $0.5 \mathrm{mg} / \mathrm{ml}$ extract concentration for PC-3, MCF-7 cell lines. While LNCaP cell viability were more than $70 \%$ with $0.05,0.125,0.25$ and $0.5 \mathrm{mg} / \mathrm{ml}$ from leave extracts after 24 hours compared with the control group (Table $1 \&$ Figure 1).

C. persicum tubers extract appeared to be the most effective extract compared to the leaves extract applied to the PC-3, MCF-7 and LNCaP cells. It can be seen that LNCaP cells were more resistant to the treatment with $C$. persicum tubers extract compared with other cell lines.

\section{Discussion}

Most of the currently used anticancer drugs are highly toxic, expensive, and resistance mechanisms pose a significant problem (Hait and Hambley, 2009; Alzeer et al., 2014). There is a continuing need to identify new drug candidates that are more effective, widely available and less toxic. Plants extracts are an important source of potentially useful compounds for the development of new anticancer drugs.

In our study we investigated ethanolic extraction of $C$. persicum Palestinian medicinal plant for cytotoxic activities against breast and prostate adenocarcinoma cell lines. Results reported that $C$. persicum showed strong 
cytotoxic activity against PC-3, MCF-7 and LNCaP cell lines with an inhibition of $>90 \%$ at $0.5 \mathrm{mg} / \mathrm{ml}$ (Table 1$)$. C. persicum is currently used for anticancer treatments in traditional Palestinian medicine (Khalilia, 2001; AliShtayeh and Jamous, 2008; Ali- Shtayeh et al., 2011). The anti-oxidant properties of this species have been previously evaluated, which suggested the possibility of anti-proliferative potential for these plants (Metın et al. 2013; Mazouz and Djeddi, 2014 and Jaradat et al. 2015). Although the cytotoxicity of C. persicum has been previously reported on breast, colon, hepatocellular carcinoma, lung, pancreatic and cervical cancer cell lines (Yildiz et al., 2013; El Hosry et al., 2014). Therefore, this plant extracts with significant cytotoxic activity should be further assessed using animal models.

Results of this study shows the inhibitory effect against the three cell lines varied significantly between the two $C$. persicum extracts. At concentration of $0.5 \mathrm{mg} / \mathrm{ml}$, tubers extract was the most toxic ( $>90 \%$ inhibition). While leaves extract showed inhibition effect less than 70\%. Cyclamen spp (Primulaceae) are rich in toxic saponins, known to have interesting biological activities (Spoerke et al., 1987; Çaliş et al., 1997; Altunkeyik et al., 2012; Sajjadi et al., 2016; Stanojević et al., 2018). In a study conducted by El Hosry et al., 2014, showed the remarkable cytotoxic activity of saxifragifolin B (saponin derived from cyclamen species), against breast adenocarcinoma and lung carcinoma and its chemo protective activity against mitomycin $\mathrm{C}$.

From our results, MCF-7 cells exhibited the highest sensitivity to the $C$. persicum extracts, with lower $\mathrm{IC}_{50}$ values as compared to PC-3 and LNCaP cell lines evaluated. These results are agreement with previous studies on various plant extracts (Yaacob et al., 2010; Subarnas et al., 2012). In order to identify the bioactive component(s) and to further understand the mechanism of action of $C$. persicum extracts should be evaluated.

\section{Conclusion}

The results of the present study demonstrated that the extracts of $C$. persicum tubers and leaves possessed strong cytotoxic activity and can be easily accessible source of natural anticancer products in cell cultures. C. persicum tubers extract appeared to be more effective compared to the leaves extract applied to the PC-3, MCF-7 and LNCaP cells. These results justified the use of $C$. persicum in traditional medicine.

The researcher decaled that the components responsible for antitumor activity of the extracts of $C$. persicum are unclear. Future studies will be aimed at investigating the effects of different parts of $C$. persicum upon isolating and identifying the substances responsible for the anticancer effects of the solvent extracts. We hope that the results of this study will play an important role in designing and developing natural anticancer drugs and will make contributions to other studies that might be conducted in this area.

\section{References}

Ali-Shtayeh, M. S., \& Jamous, R. M. (2014). BERC 2014 "National list of medicinal plants in Palestine - West Bank and Gaza Strip. Til, Nablus (Palestine): Biodiversity \& Environmental Research Center-BERC.

Ali-Shtayeh, M. S., Jamous, Rana M., \& Jamous, R. M. (2011). Herbal preparation uses by patients suffering from cancer in Palestine. Complementary Therapies in Clinical Practice 17 (4): 235-240.

Ali-Shtayeh, M. S., Yaniv, Z., \& Mahajna, J. (2000). Ethnobotanical survey in the Palestinian area: A classification of the healing potential of medicinal plants. Journal of Ethnopharmacology 73:221-232.

Ali-Shtayeh, M.S., Assali, A.A., Jamous, R.M. (2013). Antimicrobial activity of Palestinian medicinal plants against acne-inducing bacteria. African Journal of Microbiology research 7(21): 2560-2573.

Ali-Shtayeh, M.S., Jamous, R. M. (2008). Traditional Arabic Palestinian Herbal Medicine, TAPHM. Til, Nablus, Palestine, Biodiversity and Environmental Research Center, BERC.

Altunkeyik, H., Gulcemal,D., Masullo, M., Alankus-Caliskan, O., Piacente, S., Karayildirim,T. (2012). Triterpene saponins from Cyclamen hederifolium. Phytochemistry, 73, 127-133.

Alzeer, J., Vummidi, B. R., Arafeh, R., Rimawi, W., Hatem Saleem, H., and Luedtke, N. W. (2014). The influence of extraction solvents on the anticancer activities of Palestinian medicinal plants. Journal of Medicinal Plant Research, 8(8), 408-415.

Al-zuabe, M., Ismail, Y., Hasan, D., Alhrout, H., Al-Zeidaneen, S., Albawarshi, Y., \& Abu-Hamra, E. (2019). Antimicrobial Effect of Cyclamen persicum Tuber Extracts Against Bacteria and Candida Species. Journal of Pure and Applied Microbiology, 13(1), 107-116. https://doi.org/10.22207/JPAM.13.1.11

Bahk, J.Y., Hyun, J.S., Lee, H., kim, M. O., Cho, G.J., Lee, B.H. and Choi, w.s. (1998). Expression of gonadotorpin-releasing hormone $(\mathrm{GnRH})$ and $\mathrm{GnRH}$ receptor mRNA in prostate cancer cells and effect of GnRH on the proliferation of prostate cancer cells. Urol. Res. 26:259-264.

Çaliş, İ., Şatana, M. E., Yürüker, A., Demirdamar, R., Alaçam, R., Tanker, N., Sticher, O. (1997). Triterpene Saponins from Cyclamen mirabile and Their Biological Activities. Journal of Natural Products, 60(3), 315318.

Çelemli, Ö.G., Temizer, İ. K., Altınözlü, H. (2015). Anatomy, Palynology of Endemic Cyclamen pseud-ibericum in Mediterranean Phytogeographic Region of Turkey and Chemical Analysis of Its Tuber Extracts. Hacettepe J. Biol. \& Chem., 43 (2), 105-113 
Eilon, G.F., Gu, J., Slater, L.M., Hara, K., and Jacobs, J.w. (2000). Tumor apoptosis induced by expocidecontaining piperazies, a new class of anti-cancer agents. Cancer Chemother Pharmacol. 45:183-191.

El Hosry, L., Di Giorgio, C., Birer, C., Habib, J., Tueni, M., Bun, S.-S., ... Elias, R. (2014). In vitro cytotoxic and anticlastogenic activities of saxifragifolin B and cyclamin isolated from Cyclamen persicum and Cyclamen libanoticum. Pharmaceutical Biology, 52(9), 1134-1140.

Fernández-Campos, F., Clares, B., Rodríguez-Lagunas, M. J., Jauregui, O., Casals, I., \& Calpena, A. C. (2019). Ex-Vivo and In-Vivo Assessment of Cyclamen europaeum Extract After Nasal Administration. Pharmaceutics, 11(9). https://doi.org/10.3390/pharmaceutics11090426

Hait WN, Hambley TW. (2009). Targeted cancer therapeutics. Cancer Res., 69:1263-1267.

Jaradat, N. A., Abualhasan, M., and Ali, I. (2015). Comparison of Anti-Oxidant Activities and Exhaustive ExtractionYields between Wild and Cultivated Cyclamen persicum, Malva sylvestris and Urtica pilulifera Leaves. Journal of Applied Pharmaceutical Science 5 (04) 101-106.

Jaradat, N. A., Al-Ramahi, R., Zaid, A. N., Ayesh, O. I., \& Eid, A. M. (2016). Ethnopharmacological survey of herbal remedies used for treatment of various types of cancer and their methods of preparations in the West Bank-Palestine. BMC Complementary and Alternative Medicine, 16, 93.

Kelner, M.J., McMorris, T.C., Monotoya, M.A., Estes, L., Uglik , S.F., Rutherford , M., Samson , K. M., Bagnell ,R.D., and Taetle, R. (1998). Characterization of cylfulvene histospecific toxicity in human tumer cell lines. Cancer chemother. Pharmacol. 41: 237-242.

Khalilia, Walid (2001). Medicinal Plants as a source of therapeutics for the Treatment of Hormone-Refractory Prostate Cancers. MSc. Thesis, An-Najah University, Nablus.

Mazouz, W. and Samah Djeddi, S. (2014). Biological properties of Algerian Cyclamen africanum extracts. Advances in Environmental Biology, 8(4): 900-903.

Metın, H., Aydın, C., Ozay,C., and Mammadov, R. (2013). Antioxidant Activity of the Various Extracts of Cyclamen graecum Link Tubers and Leaves from Turkey. J.Chem.Soc.Pak., 35 (5),

Ozcan, G., Dagdeviren Ozsoylemez, O., Akman, G., Khalilia, W., Tezel Yetiz, B., Karagoz, A., Sutlupinar, N. (2016). Screening for antitumor activity of various plant extracts on HeLa and C 4-I cell lines. Journal of B.U.ON.: Official Journal of the Balkan Union of Oncology, 21(6), 1552-1560.

Sajjadi ST., Saboora A., and Mohammadi P. (2016). Comparison of aglycon and glycosidic saponin extracts of Cyclamen coum tuber against Candida spp. Curr Med Mycol., 2(2): 40-44.

Spoerke, D. G., Spoerke, S. E., Hall, A., \& Rumack, B. H. (1987). Toxicity of Cyclamen persium (Mill). Veterinary and Human Toxicology, 29(3), 250-251.

Srivastava, R.K., Sirvastava, A.R., Korsmeyer, S.J., Nesterova, M., Cho-chung, Y. S., and Longo, D.L. (1998). Involovement of microtubules in the regulation of $\mathrm{BCl} 2$ Phosoporylation and apoptosis through cyclic AMPDependent Protein Kinase - molecular and cellular Biology 18(6): 3509-3517.

Stanojević, L., Cvetković, D., Savić, S., Petrović, S., \& Cakić, M. (2018). Bioactive compounds and mineral composition of the aqueous extract from wild cyclamen (Cyclamen purpurascens Mill.) tubers. Advanced Technologies, 6.

Subarnas, A., Diantini, A., Abdulah, R., Zuhrotun, A., Yamazaki, C., Nakazawa, M. and Koyama, H. (2012). Antiproliferative activity of primates-consumed plants against MCF-7 human breast cancer cell lines. E3 Journal of Medical Research, 1(4), 038-043.

Yaacob, N. S., Hamzah, N., Nik Mohamed Kamal, N. N., Zainal Abidin, S. A., Lai, C. S., Navaratnam, V., \& Norazmi, M. N. (2010). Anticancer activity of a sub-fraction of dichloromethane extract of Strobilanthes crispus on human breast and prostate cancer cells in vitro. BMC Complementary and Alternative Medicine, $10,42$.

Yildiz, M., Bozcu, H., Tokgun, O., Karagur, E. R., Akyurt, O., \& Akca, H. (2013). Cyclamen exerts cytotoxicity in solid tumor cell lines: a step toward new anticancer agents? Asian Pacific Journal of Cancer Prevention: APJCP, 14(10), 5911-5913. 